\title{
Environmental assessment of applicability of mineral-organic composite for landfill area rehabilitation
}

\author{
Kamila Mizerna ${ }^{1, *}$, Anna Król ${ }^{1}$, and Adrian Mróz ${ }^{2}$ \\ ${ }^{1}$ Opole University of Technology, Department of Environmental Engineering, 5 Mikołajczyka Str., 45-271 Opole, Poland \\ ${ }^{2}$ Gogolin Municipal Multi-branch Enterprise, 15 Ligonia Str., 47-320 Gogolin, Poland
}

\begin{abstract}
This paper undertakes an assessment of the impact of a mineral-organic composite on the environment as well as the potential for its application for land rehabilitation purposes. The analysis involves the release of the leachable contaminations from the material subjected to testing. This material was formed by a composite manufactured on the basis of communal bottom ash and stabilized sewage sludge. The sludge resulting from wastewater treatment was subjected to stabilization and dehydration in waste pounds at the phase of pre-watering until $20 \%$ of dry mass is obtained. Subsequently, they were mixed with bottom ash, which was obtained from selective waste collection, in a 1:1 mass ratio. The analysis involved the leaching of inorganic contaminants in the form of heavy metals, sulphates (VI), chlorides, and fluorides as well as organic compounds in the form of organic carbon solution under the effect of leachant with a various level of $\mathrm{pH}$. The analysed components were characterized by various leaching behaviour depending on the leachant $\mathrm{pH}$. On the basis of the results, it was able to assess the potential hazard posed by the examined material on the environment as a consequence of its application for landfill area rehabilitation.
\end{abstract}

\section{Introduction}

The landfill rehabilitation process is the restoration or reallocation of the utility value to degraded land as a result of the deposition of waste, through proper land formation, improvement of chemical and physical properties, restoration of soil and regulation of proper water relations [1]. Rehabilitation of the landfill can be carried out in the technical, biological or target site management. Excavation areas require reclamation by initiating soil-forming processes in reclaimed substrate, but above all, the restoration of plant cover. Technical reclamation consists of neutralizing the substrate acidity by liming and mineral fertilization, also biological reclamation through organic fertilization and the introduction of properly selected species of pioneer plants [2,3].

The principal goal of the reclamation ought to be the minimization of potential destructive impacts on the environment [4]. According to the Regulation [5], landfill site rehabilitation should be performed in a way that protects the landfill from harmful effects on surface water and groundwater and air. Moreover, it is implemented in a way that integrates the area of the landfill with the surrounding environment and allows to observe the impact of the landfill on the environment. Reclamation works are the final stage of the operation and the day of completion of rehabilitation process is the same day that the landfill is closed. Non-waste materials or well-defined waste, including stabilized sludge and bottom ashes, are used for reclamation. The ash should be mixed prior to application in a 1: 1 ratio with dehydrated stabilized municipal sewage sludge. The use of sewage sludge as a reclamation material gives the municipal utilities the ability to manage this type of waste by own means. Likewise, this action is most desirable in waste management, where direct storage of unprocessed sewage sludge is not permitted [6].

In order to assess the potential environmental impact of materials used in reclamation, a leaching compliance test [7] shall be performed to provide information on the release of a given component from the material into the aquatic environment. The most dangerous contaminants are the heavy metals (mainly mercury, thallium, arsenic, cadmium and lead). Therefore, many studies on the content and leaching of heavy metals from waste materials of various origins are carried out worldwide [815]. Waste materials deposited in the natural environment are exposed to various physical, biological and chemical factors affecting the mobility of heavy metals. Contaminants in waste, exposed to water, can be leached into the soil and into surface and groundwater [16]. Thus, before the introduction of waste into the environment, the entrepreneur is obliged to carry out a leaching compliance test to assess the extent of their mobility to the environment.

The aim of the study was the assessment of leaching of mineral-organic composite produced on the basis of two communal wastes, i.e. stabilized sewage sludge and bottom ash from small scale boilers from households.

* Corresponding author: mizerna.kamila@gmail.com 
The tested material shall be the subject of the reclamation of communal landfills. For this purpose, the leaching of inorganic contaminants: heavy metals, chlorides $\left(\mathrm{Cl}^{-}\right)$, fluorides $\left(\mathrm{F}^{-}\right)$and sulphates (VI) $\left(\mathrm{SO}_{4}{ }^{2-}\right)$ were analysed. The content of organic compounds in the form of dissolved organic carbon (DOC) was also evaluated. A leachant of varying $\mathrm{pH}$ was used to potentially assess the change of the environmental reaction to the level of contaminant release. The role of applying composite is to create a humus layer and create a suitable habitat for vegetation development. Used for rehabilitation of land requires mixing with the top layer of soil. Applied for macro levelling, cover layer formation and bulk filling should be properly applied and scraped to achieve an effect consistent with the land development project.

\section{Materials and methods}

The research material was a mineral-organic composite produced on the basis of communal bottom ash and stabilized sewage sludge. The waste came from one of the municipality in Poland in the Opole province. The sludge formed during the extraction and compaction stages were subjected to a stabilization process based on the oxygen distribution of the organic mass. It was carried out in a sludge stabilization chamber. The sludge was then aerated by aeration grate with membrane diffusers. Subsequently, it was dehydrated on the filter press and settling plots to $20 \%$ of dry mass. Stabilized sewage sludge was mixed in a 1:1 mass ratio with household furnace ash derived from selective waste collection. The mineral-organic composite is shown in Fig. 1. The samples for research were collected by quartering from the wastewater treatment plant and transferred immediately to the laboratory. A representative laboratory sample of about $2 \mathrm{~kg}$ was prepared from which a number of test portions were formed afterwards.

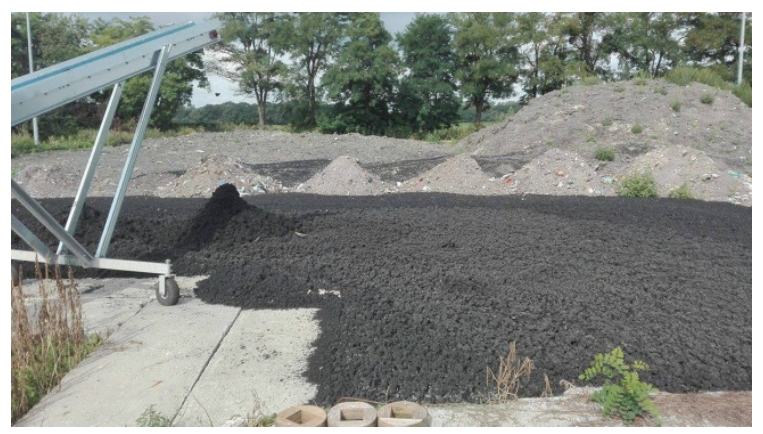

Fig. 1. Mineral-organic composite at waste management plant.

Leaching compliance test was performed on composite based on the basic test in accordance with EN 12457-2: 2002 [7]. A sample of $<4 \mathrm{~mm}$ was arranged from which water extracts were prepared at a liquid to solid ratio of $\mathrm{L} / \mathrm{S}=10 \mathrm{dm}^{3} / \mathrm{kg}$.

Liquid with different $\mathrm{pH}(4,7,12)$ was the leachant to assess the effect of liquid reaction change on the release level of contaminants. The $\mathrm{pH}$ of water was lowered by using nitric acid (V) and raised with sodium hydroxide. The extracts were shaken on a laboratory shaker for 24 hours, and the slurry was filtered. Analysis of heavy metal concentrations was carried out by flame atomic absorption spectrometry (FAAS) and inductively coupled plasma atomic emission spectrometry (ICP$\mathrm{OES})$. The content of anions $\left(\mathrm{F}^{-}, \mathrm{Cl}^{-}, \mathrm{SO}_{4}^{2-}\right)$ was determined by ion chromatography.

\section{Results and discussion}

Sewage sludge for many wastewater treatment plants and municipal facilities become a problem in terms of their disposal [17]. New ways of their utilization are constantly being sought. Hence, attempts have been made to use sludge in combination with communal bottom ash as a material for landfill rehabilitation (mineral-organic composite). Stabilized sewage sludge being a component of the test material was characterized by an annual average content of heavy metals within the range given in Table 1 . The waste was characterized by the highest content of $\mathrm{Cu}$ and $\mathrm{Zn}$. These elements can be derived from domestic wastewater, as well as industrial wastewater and surface runoff. They can also be present in wastewater as a result of corrosion of sewer pipes. Sewage sludge meets the requirements of Regulation [6] for heavy metals content in the sewage sludge used in land rehabilitation. The next part of hereby paper presents the results of the chemical composition and the leachability of contaminants from the composite in order to assess the possibility of its use as a reclamation material.

Table 1. Annual average content of heavy metals in the stabilized sewage sludge.

\begin{tabular}{|c|c|}
\hline Heavy metal & $\begin{array}{c}\text { Total content } \\
\text { [mg/kg d.m. }\end{array}$ \\
\hline Cadmium $(\mathrm{Cd})$ & 3.63 \\
\hline Copper $(\mathrm{Cu})$ & 1900 \\
\hline Nickel $(\mathrm{Ni})$ & 12.7 \\
\hline Lead $(\mathrm{Pb})$ & 36.8 \\
\hline Zinc $(\mathrm{Zn})$ & 1167 \\
\hline Mercury $(\mathrm{Hg})$ & 0.15 \\
\hline Chromium $(\mathrm{Cr})$ & 17.6 \\
\hline
\end{tabular}

Table 2 shows the content of oxide forms of components present in the material. Results of the analyses indicate a significant content in the dry matter of nutrients, mainly silicon, as well as iron, magnesium, aluminium, sulphur, calcium and sodium and less potassium. Additionally, a high ignition loss of $18.6 \%$ and a total organic carbon (TOC) content of $13.0 \%$ were also determined.

Water extracts were prepared from the test composite to determine the level of leaching of contaminants that may adversely affect the soil and water environment. A leachant of different $\mathrm{pH}$ was used for their preparation. 
The results obtained were compared with the values approved for non-hazardous and inert landfills (Table 3), which include communal waste disposal sites, according to the Regulation of the Minister of Environment dated 16 July 2015 on the acceptance of waste for landfill disposal [18]. The leaching criteria were determined at $\mathrm{pH}$ of leachant around 7. The tested material is used for rehabilitation of non-hazardous and inert landfills, hence the results are compared with these criteria.

Table 2. Chemical composition of mineral-organic composite.

\begin{tabular}{|c|c|}
\hline Properties & Content [wt. \%] \\
\hline Loss on ignition & 18.6 \\
\hline $\mathrm{TOC}$ & 13.0 \\
\hline $\mathrm{SiO}_{2}$ & 37.5 \\
\hline $\mathrm{Fe}_{2} \mathrm{O}_{3}$ & 5.57 \\
\hline $\mathrm{MgO}$ & 4.67 \\
\hline $\mathrm{Al}_{2} \mathrm{O}_{3}$ & 2.15 \\
\hline $\mathrm{SO}_{3}$ & 1.93 \\
\hline $\mathrm{CaO}$ & 1.44 \\
\hline $\mathrm{Na}_{2} \mathrm{O}$ & 1.10 \\
\hline $\mathrm{K}_{2} \mathrm{O}$ & 0.95 \\
\hline
\end{tabular}

Table 3. Concentrations of the released components of the composite at a $\mathrm{pH}$ of the leachant of 4, 7 and 12 compared to the limit values according to the Regulation [18]

\begin{tabular}{|c|c|c|c|c|}
\hline \multirow{2}{*}{ Component } & \multicolumn{3}{|c|}{$\begin{array}{c}\text { Content in water extract } \\
{[\mathrm{mg} / \mathrm{kg}]}\end{array}$} & \multirow{2}{*}{$\begin{array}{c}\text { Limit } \\
\text { value [18] } \\
\text { of } \\
\text { leaching } \\
\text { [mg/kg] }\end{array}$} \\
\hline & pH 4 & pH 7 & pH 12 & \\
\hline $\begin{array}{c}\text { Dissolved } \\
\text { organic carbon } \\
\text { (DOC) }\end{array}$ & 1370 & 1410 & 1150 & 800 \\
\hline Fluorides $\left(\mathrm{F}^{-}\right)$ & 1.20 & 1.20 & 1.00 & 150 \\
\hline Chlorides $\left(\mathrm{Cl}^{-}\right)$ & 1110 & 1140 & 1100 & 15000 \\
\hline Sulphur $\left(\mathrm{SO}_{4}{ }^{2-}\right)$ & 17500 & 18000 & 17500 & 20000 \\
\hline Barium (Ba) & 0.80 & 0.90 & 0.70 & 100 \\
\hline Zinc (Zn) & 0.26 & 0.25 & 0.72 & 50 \\
\hline Copper $(\mathrm{Cu})$ & 3.06 & 3.00 & 3.17 & 50 \\
\hline Lead $(\mathrm{Pb})$ & $<0.50$ & $<0.50$ & $<0.50$ & 10 \\
\hline Nickel (Ni) & 0.20 & 0.19 & 0.17 & 10 \\
\hline Cadmium (Cd) & $<0.05$ & $<0.05$ & $<0.05$ & 1 \\
\hline Arsenic (As) & 0.12 & 0.12 & 0.13 & 2 \\
\hline $\begin{array}{c}\text { Chromium } \\
\left(\mathrm{Cr}_{\text {total }}\right)\end{array}$ & 0.08 & 0.08 & 0.07 & 10 \\
\hline $\begin{array}{l}\text { Molybdenum } \\
\text { (Mo) }\end{array}$ & 2.44 & 2.36 & 2.36 & 10 \\
\hline Antimony (Sb) & 0.18 & 0.19 & 0.20 & 0.7 \\
\hline Selenium (Se) & 0.07 & 0.08 & 0.07 & 0.5 \\
\hline Mercury (Hg) & $<0.008$ & $<0.008$ & $<0.008$ & 0.2 \\
\hline
\end{tabular}

Among the anions at the highest level of leaching were sulphates $(17500-18000 \mathrm{mg} / \mathrm{kg})$, chlorides (1100$1140 \mathrm{mg} / \mathrm{kg}$ ) and fluorides (1.00-1.20 mg/kg). Regarding heavy metals, the leaching was in the following decreasing series: $\mathrm{Cu}>\mathrm{Mo}>\mathrm{Ba}>\mathrm{Zn}>\mathrm{Sb}>\mathrm{Ni}>\mathrm{As}>\mathrm{Cr}$. Very toxic metals such as $\mathrm{Pb}, \mathrm{Cd}$ and $\mathrm{Hg}$ are below the limit of determination. The content of non-metal Se, which the high concentration in the organism could be dangerous was also analysed in water extracts. No exceedance of permissible leaching values in Regulation [18] was observed for all concentrations of elements. The only component not meeting the leaching criteria was dissolved organic carbon (DOC), which acceptable concentration in water extract prepared with a $\mathrm{pH} 7$ leachant was exceeded by $610 \mathrm{mg} / \mathrm{kg}$. However, the high value of this parameter should not become an obstacle when applying this material in landfill rehabilitation. Organic substances occur also naturally in the environment, and any leachate from the composite upon entry into ground or surface waters may be diluted. Moreover, the organic matter contained in water can complex heavy metals and limit further migration in the environment [19].

There were slight differences in the majority of concentrations of the test components depending on the $\mathrm{pH}$ of water used. However, the use of leachant with $\mathrm{pH}$ 12 resulted in a $18 \%$ reduction in DOC leaching, $17 \%$ in $\mathrm{F}^{-}$, and $\mathrm{Ba}$ in $22 \%$, relative to $\mathrm{pH} 7$. While it contributed to the increase in the $\mathrm{Zn}$ concentration of $188 \%$. Scientific research of heavy metal leaching conducted in Poland and worldwide prove [12-14, 20, 21] that heavy metal cations, including zinc, are generally characterized by an increased tendency to release in acidic environment. Still, based on the research results, it is clear that this correlation is not close and leaching of heavy metals can be influenced by many factors, including the chemical composition of the material. The increase in the release level of a given contaminant to the aqueous phase, influenced by a $\mathrm{pH}$ change, may be essential during the determination of its high concentrations. At this point, lowering or increasing the liquid $\mathrm{pH}$, due to the influence of various environmental factors, may result in exceeding the allowable storage values.

\section{Conclusions}

The obtained test results allow to state that the mineral-organic composite is an environmentally safe material when used for rehabilitation purposes. Concentrations of components (heavy metals, chlorides, fluorides, sulphates) which could pose a risk to the aquatic environment in the water extracts did not exceed the normative limit values. The use of leachant with acidic and base character did not contribute to a significant increase in leaching of the analysed components. Zinc was the only element, during the process of leaching at $\mathrm{pH} \mathrm{12,} \mathrm{with} \mathrm{nearly} \mathrm{3-times}$ increased concentration when compared with the use of neutral water. Due to the composition of the tested material, its introduction into the top layer of the landfill 
site may contribute to the increase of the organic matter content and to the growth of the nutrient components, mainly silicon, iron and magnesium. Increasing the amount of organic matter is conducive to the formation of humus levels and increasing the content of assimilable forms of nutrients. These processes in turn, create conditions for the development of vegetation in degraded land.

\section{References}

1. K. d'Obyrn, W. Wójcik, AUNC Ekonomia XLVI, 2, 225-237 (2015) doi: dx.doi.org/10.12775/AUNC ECON.2015.014

2. S. Góral, Ecol. Eng. 3, 161-178 (2001), http://www.archive.ineko.net.pl/pdf/IE-3.pdf

3. K. Klimont, Probl. Inż. Rol. 2, 165-176 (2011), http://www.itp.edu.pl/wydawnictwo/pir

4. J. Kurian, S. Esakku, R. Nagendran, C. Visvanathan, 2005. A decision making tool for dumpsite rehabilitation in developing countries. Proceedings of Sardinia 2005, Tenth International Waste Management and Landfill Symposium, S. Margherita di Pula, Italy (2005)

5. Regulation of the Minister of Environment of 30 April 2013 on landfills, Poland's Journal of Laws, 2013, item 523

6. Regulation of the Minister of Environment of 6 February 2015 for municipal sewage sludge, Poland's Journal of Laws, 2015, item 257

7. EN 12457-2:2002 Characterisation of waste. Leaching. Compliance test for leaching of granular waste materials and sludges. Part 2

8. M. Bożym, I. Florczak, P. Zdanowska, J. Wojdalski, M. Klimkiewicz, Renew. Energy, 77, 467-472 (2015), doi: http://dx.doi.org/10.1016/j.renene.2014.11.010

9. A. Król, Przem. Chem. 10, 971-973 (2007)

10. A. Król, Environ. Prot. Eng. 38, 4, 29-40 (2012), doi: 10.5277/EPE120403

11. T. Olszowski, M. Bożym, Atmos. Environ. 94, 2227 (2014), doi : 10.1016/j.atmosenv.2014.05.011

12. M.J. Quina, J.C.M. Bordado, R.M. Quinta-Ferreira, Waste Manage. 29, 2483-2493 (2009), doi: 10.1016/j.wasman.2009.05.012

13. M. Vitková, V. Ettler, O. Šebek, M. Mihaljevič, Mineral. Mag. 72, 1, 521-524 (2008), doi: 10.1180/minmag.2008.072.1.521

14. V. Cappuynus, R. Swennen, J. Hazard. Mater. 158, 1, 185-195 (2008), doi: 10.1016/j.jhazmat.2008.01.058

15. M. Wzorek, T. Baran, M. Ostrowski, Cement Wapno Beton, 18, 4, 207-215 (2013)

16. H.A. van der Sloot, A. van Zomeren, Mine Water Environ. 31, 92-103 (2012), doi: 10.1007/s10230-012-0182-8
17. M. Wzorek, Ecol. Chem. Eng. S, 19, 4, 617-627 (2012), doi: https://doi.org/10.2478/v10216-0110044-5

18. Regulation of the Ministry of Economy of 16 July 2015 on the acceptance of waste for landfill, Poland's Journal of Laws, 2015, item 1277

19. W.H. Błaszczyk, Zesz. Prob. Nauk Rol. 476, 61-68 (2001)

20. K. Mizerna, A. Król, Appl. Mech. Mat. 797, 408414 (2015), doi: 10.4028/www.scientific.net/ AMM.797

21. H.A. van der Sloot, Horizontal standardization and harmonization of leaching test methods for waste, secondary raw materials, construction materials and (contaminated) soil, Proceedings of the Wascon Conference, San Sebastian (2003), https://www.ecn.nl/docs/society/leaching/wascon_0 05.pdf 